\title{
Sistem Informasi Akuntansi Arus Kas Berbasis WEB Pada CV. Simpang Ampek Jaya Kota Pontianak
}

\begin{tabular}{|c|c|}
\hline \multicolumn{2}{|r|}{ Puji Herliani } \\
\hline Info Artikel & ABSTRACT \\
\hline $\begin{array}{ll}\text { Diterima Juli 10, } 2021 \\
\text { Revisi } & \text { Agustus 10, 2021 } \\
\text { Terbit } & \text { September 10, } 2021\end{array}$ & $\begin{array}{l}\text { CV. Simpang Ampek Jaya Pontianak is a company engaged in the culinary } \\
\text { field of Padang cuisine. In the process of Cash Flow on CV. Simpang Ampek } \\
\text { Jaya Pontianak still uses a manual system in recording data and managing } \\
\text { cash inflows, outflows and recapitulation reports using book notes. The } \\
\text { methodology used is the Extreme Programming method. The results of the }\end{array}$ \\
\hline $\begin{array}{l}\text { Keywords: } \\
\text { Accounting System } \\
\text { Information } \\
\text { Website } \\
\text { Computerized }\end{array}$ & $\begin{array}{l}\text { that is able to manage incoming and outgoing cash data. This web-based } \\
\text { Cash Flow application was created using the PHP (Hypertext Preprocessor) } \\
\text { programming language as a tool and run the software, Visual Studio Code } \\
\text { text editor and its open source code, MySQL as the database, Php MyAdmin } \\
\text { as the database editor, and Xampp version } 7.2 .2 \text { as the database editor. the } \\
\text { web server. And the outputs generated in this web-based application include } \\
\text { cash inflow report data, cash out report data, and cash flow report data. With } \\
\text { this web-based cash flow application, it is expected to be able to manage } \\
\text { incoming and outgoing cash more effectively and efficiently and the } \\
\text { application system is now more conducive. }\end{array}$ \\
\hline
\end{tabular}

\section{Identitas Penulis:}

Puji Herliani

Program Studi Sistem Informasi Akuntansi Kampus Pontianak,

Universitas Bina Sarana Informatika,

Jalan Abdurahman Saleh No.18 A Pontianak,

Email: $11180128 @$ bsi.ac.id

\section{PENDAHULUAN}

Dalam setiap kegiatan pada CV. Simpang ampek jaya harus mencatat setiap kas masuk dan kas keluar perusahaan. Pencatatan kas masuk dan kas keluar serta laporan rekapulasi masih menggunakan buku catatan yang pengolahan atau prosesnya hanya menyimpan menyebabkan sering terjadi kesalahan saat mencatat dan hilangnya data arsipan yang mengakibatkan laporan keuangan yang dihasilkan menjadi tidak akurat. Selain itu, dalam pencatan laporan kas Masuk dan kas Keluar masih mengalami kesulitan karena pencatatan transaksi belum terkomputerisasi, sehingga dalam kegiatanya tersebut membutuhkan waktu yang cukup banyak mengakibatkan tidak efektifnya dalam proses pencatatan.

Dari hasil identifikasi permasalahan yang ditemukan diperlukan sebuah Sistem Informasi Akuntansi Aruskas berbasis web pada CV. Simpang Ampek Jaya pontianak dengan tujuan mempercepat dalam pencatatan kas masuk dan kas keluar secara realtime dan membutuhkan waktu yang singkat. Sistem yang dikembangkan berbasis web dengan harapan dapat memudahkan integrasi sistem informasi sebelumnya dan memudahkan proses pemeliharaan.

\section{METODE}

XP (Extreme Programming) merupakan salah satu metodologi rekayasa perangkat lunak yang banyak digunakan untuk mengembangkan aplikasi oleh para developer. Xp sangat cocok untuk pengembangan proyek yang memerlukan adaptasi cepat dalam perubahan - perubahan yang terjadi selama pengembangan aplikasi. Xp juga cocok untuk anggota tim yang tidak terlalu banyak dan berada pada lokasi yang sama dalam pengembangan sistem. (Suryantara, 2017), 
1. Planning adalah tahapan perencanaan digunakan untuk memahami konsep bisnis, pengumpulan kebutuhan sistem, menggambarkan output yang diperlukan, fitur-fitur, dan fungsionalitas yang akan dibangun menggunakan rekayasa perangkat lunak.

2. Design adalah data yang diperoleh dari tahapan planning seperti: analisa kebutuhan sistem, keluaran sistem, fitur-fitur dan fungsionalitas. Sehingga sistem dirancang menggunakan Unified Modelling Language (UML), terdiri dari Use case Diagram, Activity Diagram, Class Diagram, Squence Diagram yang mempunyai manfaat untuk pemodelan sistem yang sudah memiliki standar. Digunakan untuk dapat memastikan perangkat lunak yang akan dibangun selesai dengan tepat waktu, sesuai dengan anggaran, dan sesuai dengan spesifikasi yang ditetapkan pada tahap Planning.

3. Coding adalah tahapan pengkodean perangkat lunak yang menggunakan software Visual Studio Code (VSCode) dengan bahasa program PHP (Hypertext Preprocessor) serta framework Codelgniter 3. Selain itu dibutuhkan juga database untuk menyimpan data menggunakan Software Xampp.

4. Testing adalah tahapan akhir dari metode XP yang akan dilakukan dengan cara pengujian menggunakan blackbox testing. Pengujian dilakukan pada form login, form user,form jenis, form kas masuk, form kas keluar, form laporan Kas Masuk, form laporan kas keluar, dan form laporan arus kas.

\section{HASIL}

Setelah dilakukan perancagan, selanjutnya diimplementasikan dalam bentuk kode program. Pengkodean dengan menggunakan Vscode dengan bahasa program PHP dan database MySQL sesuai dengan fungsional yang telah ditetapkan.

1. Halaman Login System

Sumber : Hasil Perancangan (2021)

Gambar 1 Halaman Login system

Pada Gambar 1 pada gambar ini dapat dijelaaskan bahwa pada sistem halaman Login terdapat Username dan password yang harus diisi oleh ketua dan kasir untuk masuk ke halaman utama.

2. Halaman Menu Utama Kasir dan Ketua

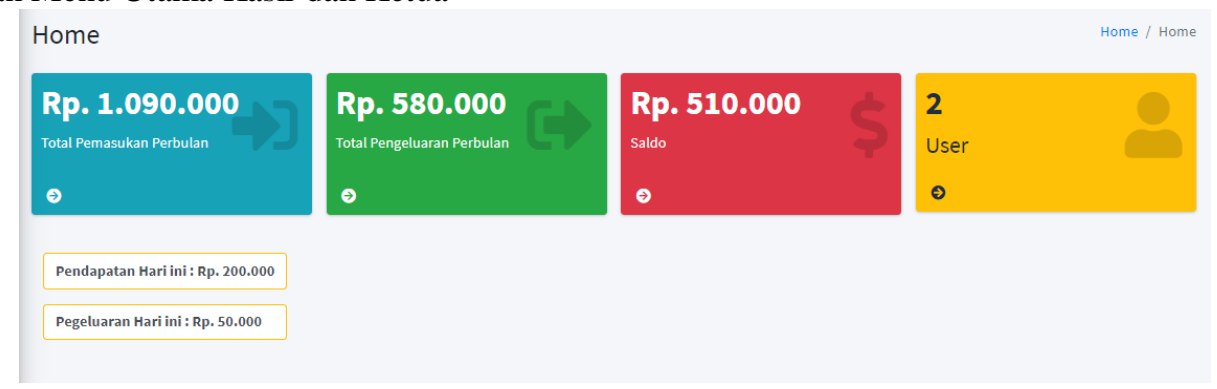

Sumber Perancangan (2021)

Gambar 2 Halaman Menu Utama Kasir dan Ketua

Pada Gambar III. 20 menjelaskan bahwa halaman menu utama Ketua dan Kasir dapat melihat Kas masuk dan kas keluar hari ini serta dapat melihat total pemasukkan, pengeluaran, saldo perbulan dan total yang mengakses user 
Vol. 02 No. 02, September 2021, pp. 68 76

E-ISSN: 2721-7523

3. Halaman Data User Ketua

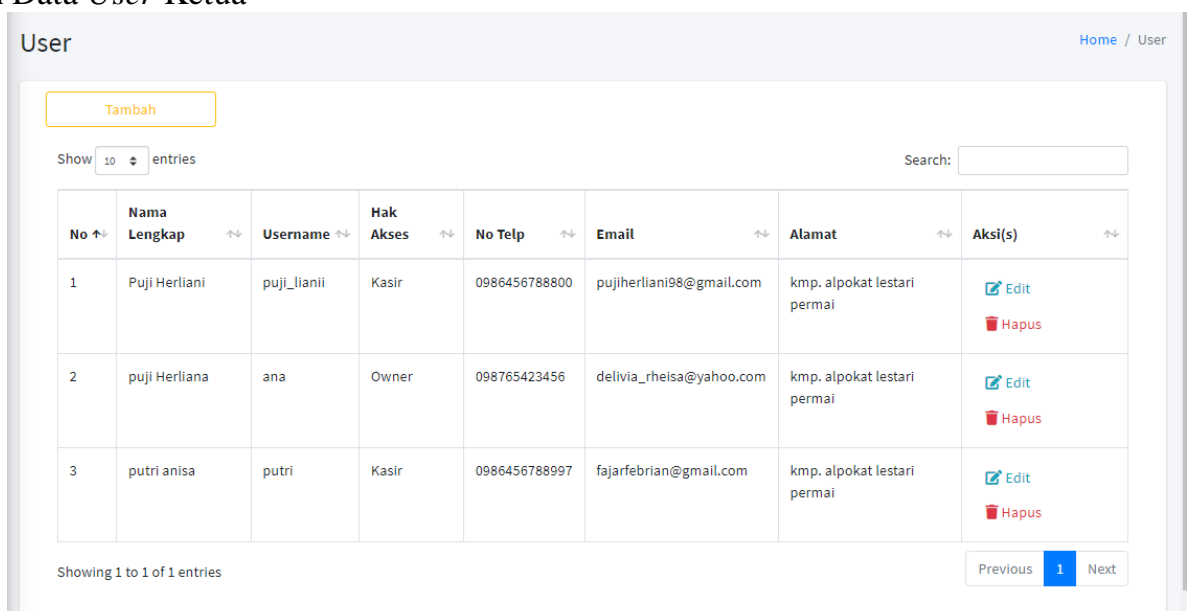

Sumber Perancangan (2021)

\section{Gambar 3 Halaman Data User Ketua}

Pada Gambar 3 pada gambar ini dijelaskan bahwa menu data user ketua terdapat no, nama lengkap, username, hak akses, no telp, email, alamat. Ketua dapat mengelola halaman dengan adanya tambah, edit,hapus pada fitur yang tersedia

4. Halaman Data Jenis Ketua

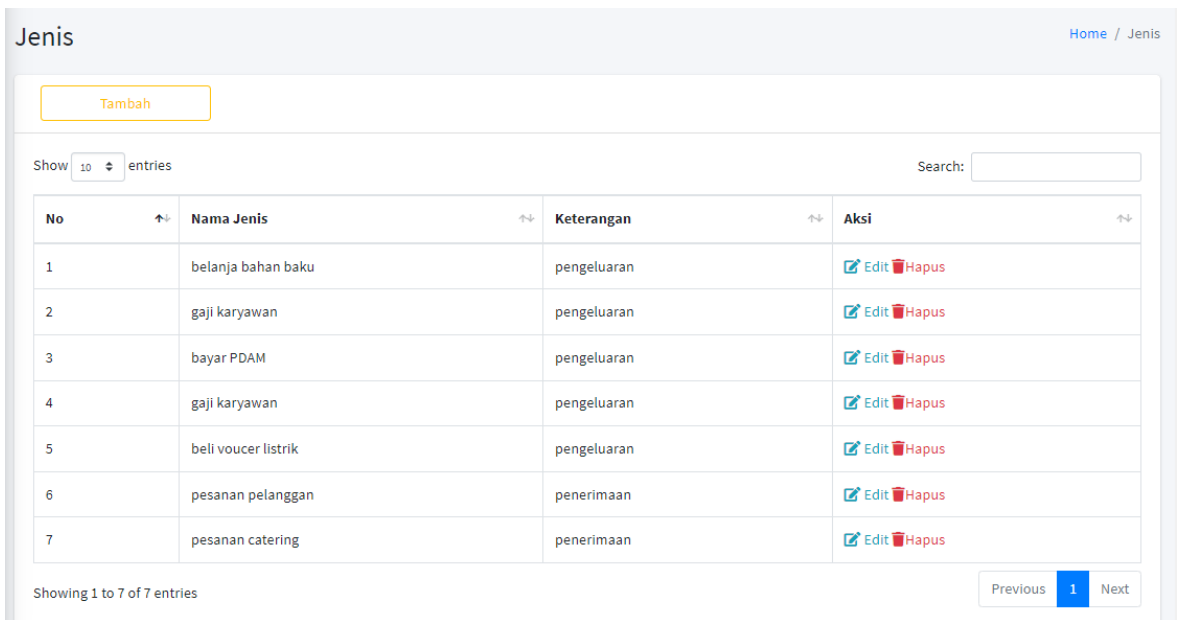

Sumber Perancangan (2021)

\section{Gambar 4 Halaman Data Jenis Ketua}

Pada Gambar III.22 pada gambar ini dijelaskan bahwa menu data jenis ketua terdapat no, nama jenis, dan keterangan. Ketua dapat mengelola halaman dengan adanya tambah, edit, hapus pada fitur yang tersedia. 
JUSTIAN, Jurnal Sistem Informasi Akuntansi

Vol. 02 No. 02, September 2021, pp. 68 76

E-ISSN: 2721-7523

5. Halaman Data Kas Masuk Ketua

\begin{tabular}{|c|c|c|c|c|c|c|c|c|}
\hline \multicolumn{8}{|c|}{ Kas Masuk } & Home / Kas Mas \\
\hline \multicolumn{9}{|c|}{ Tambah } \\
\hline \multicolumn{6}{|c|}{ Show $10 *$ entries } & \multicolumn{3}{|l|}{ Search: } \\
\hline No $\uparrow$ & No Faktur $\uparrow$ & Tanggal & User & Nama Penerimaan & Total & Keterangan & $\uparrow$ & Aksi \\
\hline 1 & FKMO002 & 2021-07-16 & Puji Herliani & pesanan pelanggan & 30000 & penerimaan & & $\widetilde{C}$ Edit \\
\hline 2 & FКм0003 & 2021-07-16 & Puji Herliani & pesanan pelanggan & 30000 & penerimaan & & Ø̋ Edit Hapus \\
\hline 3 & FKMO004 & 2021-07-24 & Puji Herliani & pesanan pelanggan & 50000 & pesanan di meja 13 & & $\widetilde{Z}$ Edit \\
\hline 4 & Fкм0005 & 2021-07-24 & Puji Herliani & pesanan catering & 250000 & pesanan polda 25 kotak & & $\boldsymbol{G}$ Edit政Haps \\
\hline 5 & FKMO006 & 2021-07-24 & Puji Herliani & pesanan catering & 350000 & pesanan kantor camat pontianak barat $20 \mathrm{kotak}$ & & $\widetilde{C}$ Edit Hapus \\
\hline \multicolumn{7}{|c|}{ Showing 1 to 5 of 5 entrles } & \multicolumn{2}{|c|}{$\begin{array}{llll}\text { Previous } & \mathbf{1} & \text { Next }\end{array}$} \\
\hline
\end{tabular}

Sumber Perancangan (2021)

\section{Gambar 5 Halaman Data Kas Masuk Ketua}

Pada Gambar 5 pada gambar ini dijelaskan bahwa menu data kas masuk ketua terdapat no, no kwitansi, tanggal, user, nama penerimaan, total, keterangan. Ketua dapat mengelola halaman dengan adanya tambah, edit,hapus pada fitur yang tersedia. 
Vol. 02 No. 02, September 2021, pp. 68 76

E-ISSN: 2721-7523

6. Halaman Data Kas Keluar Ketua

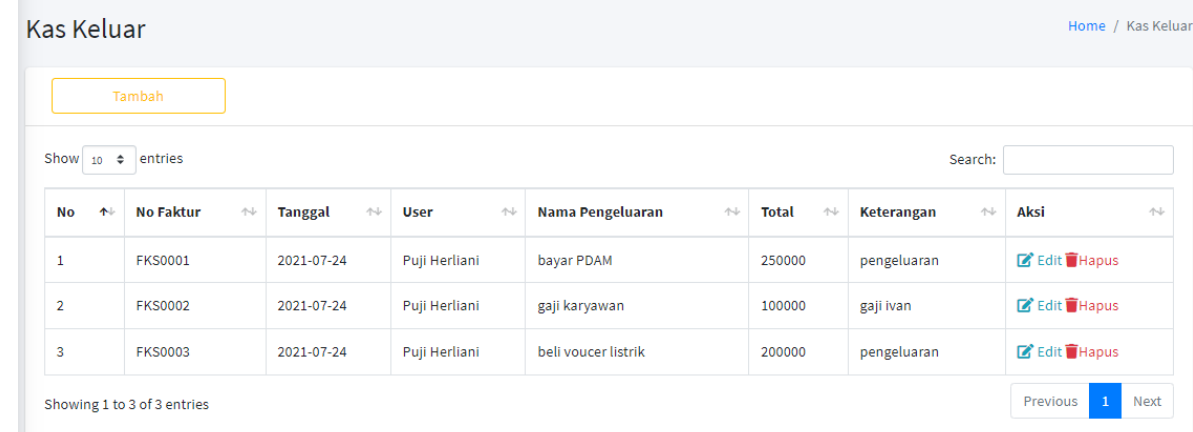

Sumber Perancangan (2021)

\section{Gambar 6 Halaman Data Kas Keluar Ketua}

Pada Gambar 6 pada gambar ini dijelaskan bahwa menu data kas keluar ketua terdapat no, no kwitansi, tanggal, user, nama pengeluaran, total, keterangan. Ketua dapat mengelola halaman dengan adanya tambah, edit,hapus pada fitur yang tersedia.

7. Halaman Data Laporan Kas Masuk Ketua

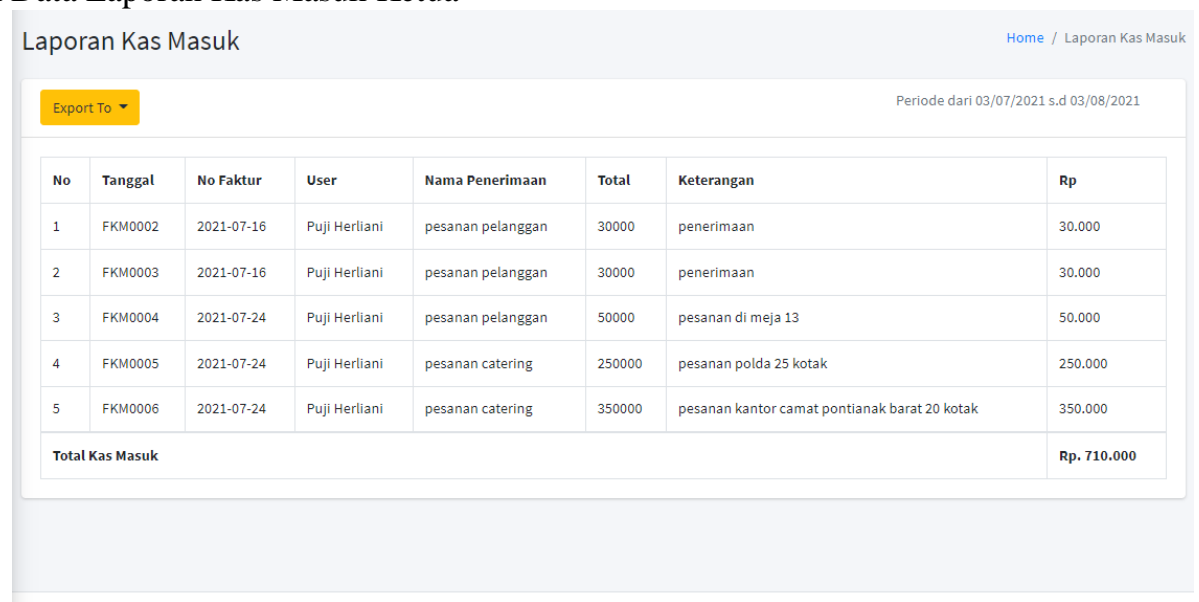

Sumber Perancangan (2021)

\section{Gambar 7 Halaman Data Laporan Kas Masuk Ketua}

Pada Gambar 7 pada gambar ini dijelaskan bahwa halaman data laporan kas masuk ketua terdapat no, no kwitansi, tanggal, user, nama penerimaan, total, keterangan, total kas masuk. Ketua dapat mengelola halaman dengan adanya print pada fitur yang tersedia.

8. Halaman Data Laporan Kas keluar Ketua

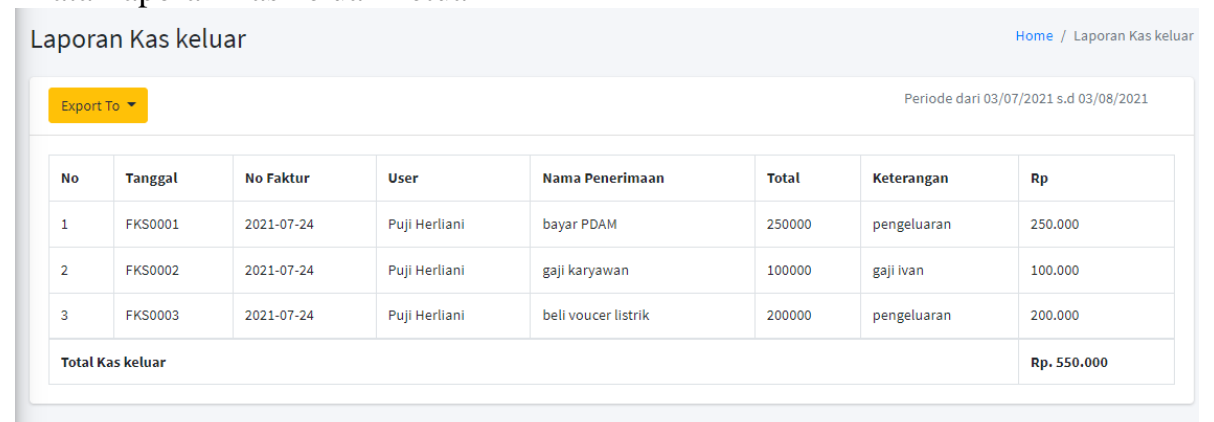

Sumber Perancangan (2021)

\section{Gambar 8 Halaman Data Laporan Kas Keluar Ketua}

Pada Gambar 8 pada gambar ini dijelaskan bahwa halaman data laporan kas keluar ketua terdapat no, no kwitansi, tanggal, user, nama pengeluaran, total, keterangan, total kas keluar. Ketua dapat mengelola halaman dengan adanya print pada fitur yang tersedia. 
Vol. 02 No. 02, September 2021, pp. 68 76

E-ISSN: 2721-7523

9. Halaman Data Laporan Arus Kas Ketua

\begin{tabular}{|c|c|c|c|}
\hline 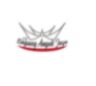 & & 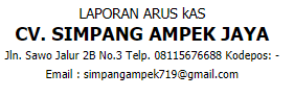 & \\
\hline \multicolumn{4}{|c|}{ Tanggal : 03 July 2021 s.d 03 August 2021} \\
\hline \multicolumn{4}{|l|}{ Penerimaan Kas } \\
\hline $16 / 07 / 2021$ & pesanan pelanggan & & 30000 \\
\hline $16 / 07 / 2021$ & pesanan pelanggan & & 30000 \\
\hline $24 / 07 / 2021$ & pesanan pelanggan & & 50000 \\
\hline 24/07/2021 & pesanan catering & & 250000 \\
\hline $24 / 07 / 2021$ & pesanan catering & & 350000 \\
\hline Total Kas Masu & & & Rp. $710.000,00$ \\
\hline \multicolumn{4}{|c|}{ Pengeluaran Kas } \\
\hline $24 / 07 / 2021$ & bayar PDAM & & 250000 \\
\hline 24/07/2021 & gaji karyawan & & 100000 \\
\hline $24 / 07 / 2021$ & beli voucer listrik & & 200000 \\
\hline Total Kas Kelua & & & Rp. $550.000,00$ \\
\hline \multicolumn{3}{|c|}{ Total Penerimaan/Pengeluaran } & Rp. $160.000,00$ \\
\hline \multirow{2}{*}{\multicolumn{3}{|c|}{$\begin{array}{l}\text { Saldo Awal } \\
\text { Saldo Akhir }\end{array}$}} & Rp. 0,00 \\
\hline & & & Rp. 0,00 \\
\hline
\end{tabular}

Sumber Perancangan (2021)

\section{Gambar 9 Halaman Data Laporan Arus Kas Ketua}

Pada Gambar 9 pada gambar ini dijelaskan bahwa halaman data laporan arus kas ketua terdapat data Laporan kas masuk dan data laporan kas keluar. Ketua dapat mengelola halaman dengan adanya print pada fitur yang tersedia.

10. Halaman Data Kas Masuk Kasir

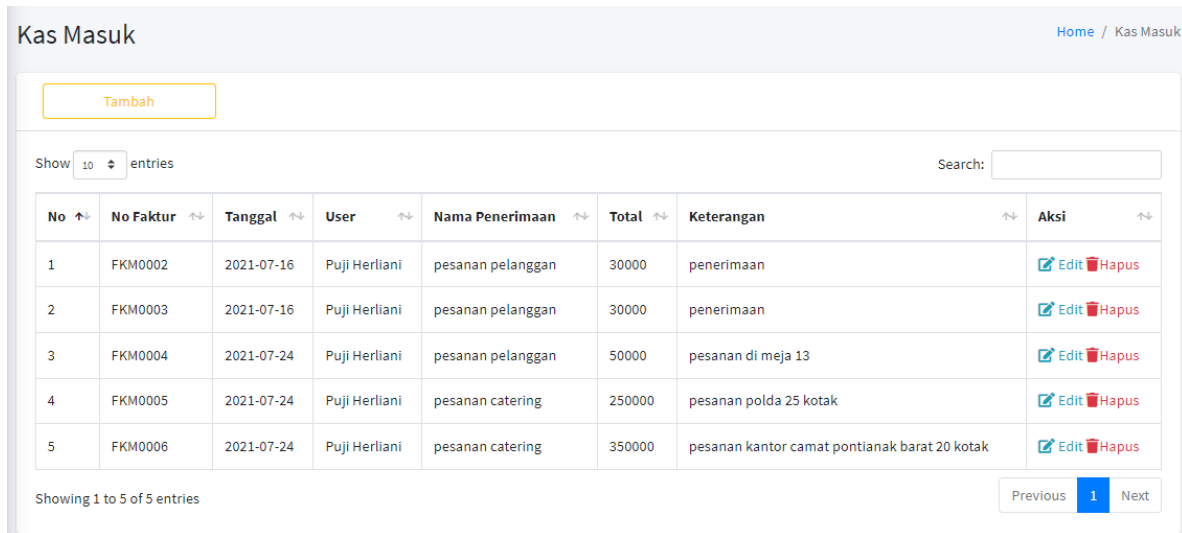

Sumber Perancangan (2021)

\section{Gambar 10 Halaman Data Kas Masuk Kasir}

Pada Gambar 10 pada gambar ini dijelaskan bahwa menu data kas masuk kasir terdapat no, no kwitansi, tanggal, user, nama penerimaan, total, keterangan. Kasir dapat mengelola halaman dengan adanya tambah, edit,hapus pada fitur yang tersedia. 
Vol. 02 No. 02, September 2021, pp. 68 76

E-ISSN: 2721-7523

11. Halaman Data Kas keluar Kasir

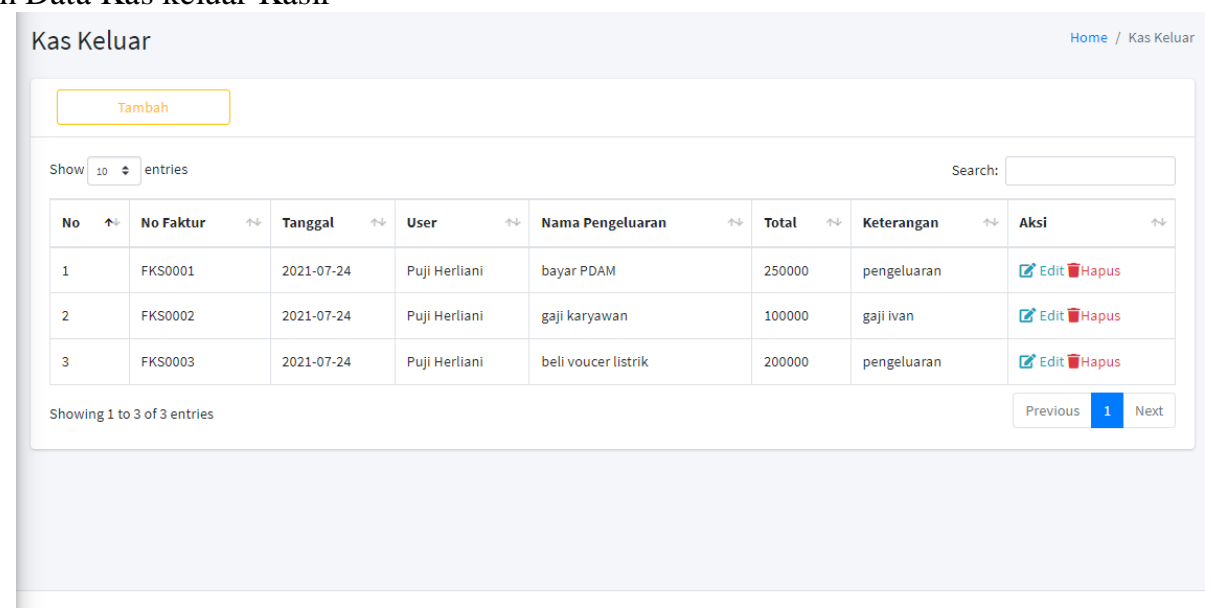

Sumber Perancangan (2021)

\section{Gambar 11 Halaman Data Kas Keluar Kasir}

Pada Gambar 11 pada gambar ini dijelaskan bahwa menu data kas keluar kasir terdapat no, no kwitansi, tanggal, user, nama pengeluaran, total, keterangan. Kasir dapat mengelola halaman dengan adanya tambah, edit,hapus pada fitur yang tersedia.

12. Halaman Data Laporan Kas Masuk Kasir

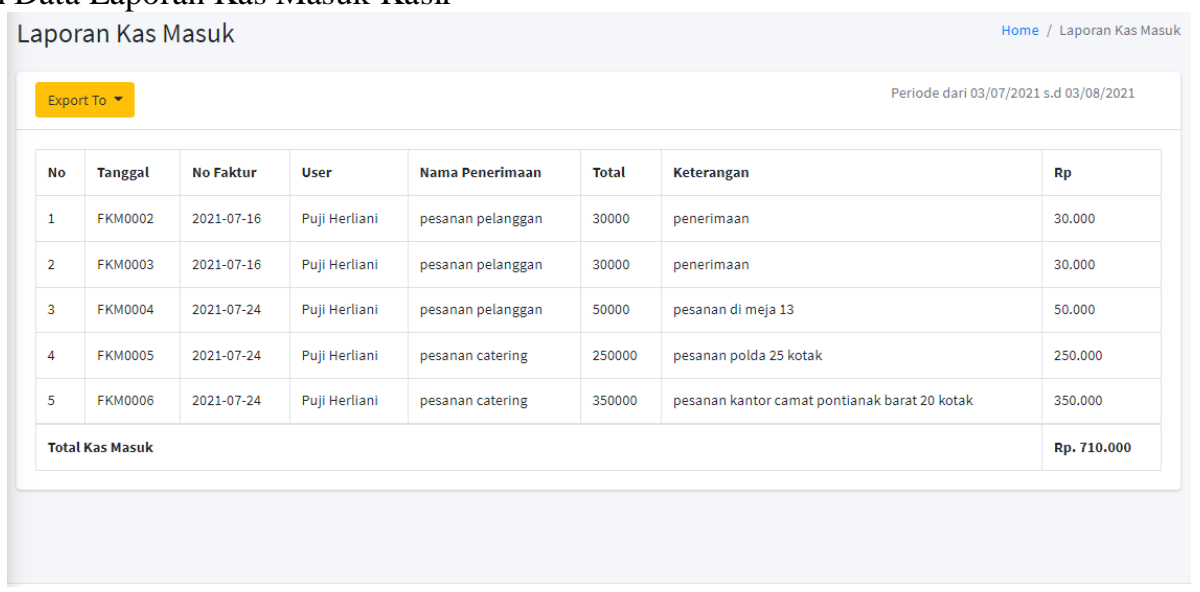

Sumber Perancangan (2021)

Gambar 12 Halaman Data Laporan Kas Masuk kasir

Pada Gambar 12 pada gambar ini dijelaskan bahwa halaman data laporan kas masuk kasir terdapat no, no kwitansi, tanggal, user, nama penerimaan, total, keterangan, total kas masuk. Kasir dapat mengelola halaman dengan adanya print pada fitur yang tersedia.

13. Halaman Data Laporan Kas Keluar Kasir

\begin{tabular}{|c|c|c|c|c|c|c|c|}
\hline \multicolumn{6}{|c|}{ Laporan Kas keluar } & & Home / Laporan Kas keluar \\
\hline \multicolumn{6}{|c|}{ Export To - } & \multicolumn{2}{|c|}{ Periode dari 03/07/2021 s.d 03/08/2021 } \\
\hline No & Tanggal & No Faktur & User & Nama Penerimaan & Total & Keterangan & $\mathrm{Rp}$ \\
\hline 1 & FKS0001 & 2021-07-24 & Puji Herliani & bayar PDAM & 250000 & pengeluaran & 250.000 \\
\hline 2 & FKS0002 & 2021-07-24 & Puji Herliani & gaji karyawan & 100000 & gaji ivan & 100.000 \\
\hline 3 & FKS0003 & 2021-07-24 & Puji Herliani & beli voucer listrik & 200000 & pengeluaran & 200.000 \\
\hline \multicolumn{7}{|c|}{ Total Kas keluar } & Rp. 550.000 \\
\hline
\end{tabular}

Sumber Perancangan (2021)

\section{Gambar 13 Halaman Data Laporan Kas Keluar Kasir}

Pada Gambar 13 pada gambar ini ini dijelaskan bahwa halaman data laporan kas keluar kasir terdapat no, no kwitansi, tanggal, user, nama pengeluaran, total, keterangan, total kas keluar. Kasir dapat mengelola halaman dengan adanya print pada fitur yang tersedia. 
14. Halaman Data Laporan Arus Kas Kasir

\begin{tabular}{|c|c|c|c|}
\hline \multicolumn{2}{|l|}{$=$} & \multicolumn{2}{|l|}{ 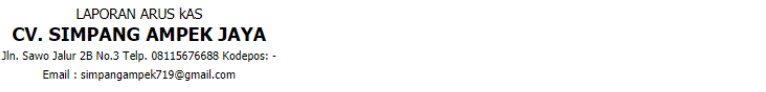 } \\
\hline \multicolumn{4}{|c|}{ Tanggal : 03 July 2021 s.d 03 August 2021} \\
\hline $\begin{array}{l}\text { Penerimaan Kas } \\
\text { 11//67/2021 } \\
16 / 77 / 2021 \\
22 / 47 / 2021 \\
24 / 77 / 2021 \\
24 / 07 / 2021 \\
\text { Total Kas Masuk }\end{array}$ & $\begin{array}{l}\text { pesanan pelanggan } \\
\text { pesanan pelanggan } \\
\text { pesanan pelanggan } \\
\text { pesanan catering } \\
\text { pesanan catering }\end{array}$ & & $\begin{array}{l}30000 \\
30000 \\
50000 \\
2500000 \\
350000 \\
\text { Rp. } 710.000,00\end{array}$ \\
\hline $\begin{array}{l}\text { Pengeluaran Kas } \\
24 / / 77 / 2021 \\
22 / 707 / 2021 \\
24 / / 7 / 2021 \\
\text { Total Kas Keluar }\end{array}$ & $\begin{array}{l}\text { bayar PDAM } \\
\text { gagikaryawan } \\
\text { beli voucer listrik }\end{array}$ & & $\begin{array}{l}2500000 \\
100000 \\
200000 \\
\text { Rp. 550.000,00 }\end{array}$ \\
\hline $\begin{array}{l}\text { Total Penerimaa } \\
\text { Saldo Awal } \\
\text { Saldo Akhir }\end{array}$ & & & $\begin{array}{l}\text { Rp. } 160.000,00 \\
\text { Rp. o, o, } \\
\text { Rp. o, o0 }\end{array}$ \\
\hline
\end{tabular}

Sumber Perancangan (2021)

Gambar 14 Halaman Data Laporan Arus Kas Kasir

Pada Gambar 14 pada gambar ini dijelaskan bahwa halaman data laporan arus kas kasir terdapat data Laporan kas masuk dan data laporan kas keluar. Kasir dapat mengelola halaman dengan adanya print pada fitur yang tersedia.

\section{KESIMPULAN}

Dari pembahasan pada bab-bab sebelumnya mengenai Sistem Informasi Akuntansi arus kas berbasis web pada CV. Simpang Ampek Jaya, maka penulis memberikan beberapa kesimpulan sebagai berikut :

a. Sistem Informasi Akuntansi arus kas pada CV. Simpang Ampek Jaya yang dirancang dapat membantu dalam pengolahan data transaksi kas masuk dan kas keluar.

b. Dengan adanya sistem yang terkomputerisasi di dalam pencatatan kas masuk dan kas keluar, kasir dan ketua tidak perlu lagi menggunakan media kertas untuk mencatat data.

c. Sistem Informasi Akuntansi Arus Kas pada CV. Simpang Ampek Jaya akan mempermudah pihak perusahaan dalam melakukan pencarian data kas masuk dan kas keluar, data tersebut tersimpan kedalam database

d. Dengan adanya Sistem Informasi Akuntansi arus kas berbasis web ini dapat membantu ketua dan kasir dalam mengakses laporan kas masuk, laporan kas keluar dan laporan arus kas.

\section{UCAPAN TERIMA KASIH}

Terima kasih kami ucapkan kepada seluruh pihak terkait atas terlaksananya penelitian ini, terutamakepada Allah swt, serta kepada pihak penerbit yang telah berkenan untuk menerbitkan paper ini.

\section{REFERENSI}

[1] Andaru, A. (2018). Pengertian database secara umum. OSF Preprints, 2.

[2] Enterprise, J. (2018). HTML, PHP, dan MySQL untuk pemula. Elex Media Komputindo.

[3] Fauzi, R. A. (2017). Sistem Informasi Akuntansi (Berbasis Akuntansi). CV Budi Utama.

[4] Haqi, B. (2019). Aplikasi SPK Pemilihan Dosen Terbaik Metode Simple Additive Weighting (SAW) Dengan Java. Deepublish.

[5] Iskandar, B., \& Hamdani, A. U. (2017). Jasa Pengiriman Barang Studi Kasus : PT. XYZ. STMIK AMIKOM Yogyakarta, $1(2), 67-72$.

[6] Kaloh, T., Ilat, V., \& Pangerapan, S. (2018). Analisis Laporan Arus Kas Untuk Menilai Kinerja Keuangan Perusahaan Makanan Dan Minuman Yang Terdaftar Di Bursa Efek Indonesia. Going Concern: Jurnal Riset Akuntansi, 14(1), 741751. https://doi.org/10.32400/gc.13.04.21872.2018

[7] Siahaan, Vivian, R. H. S. (2020). 4 books in one: tutorial JavaScript jQuery. Balige Publishing.

[8] Solichin, A. S. K. (2016). Pemrograman Web dengan PHP dan MySQL - Achmad Solichin - Google Buku. Universitas Budi Luhur, June, https://books.google.co.id/books?id=kcD4BQAAQBAJ\&printsec=frontcover\&dq=aplikasi+berbasis+web+dengan\&hl= id\&sa=X\&ved=0ahUKEwib-fT80ITYAhVBrI8KHT9GD6QQ6AEIJzAA\#v=onepage\&q=aplikasi berbasis web dengan $\& \mathrm{f}=$ false

[9] suprapto, untung. (2021). Pemodelan Perangkat Lunak. Gramedia Widiasarana Indonesia. 
JUSTIAN, Jurnal Sistem Informasi Akuntansi

Vol. 02 No. 02, September 2021, pp. 68 76

E-ISSN: 2721-7523

[10] Suryantara, I. G. nugraha. (2017). Merancang Aplikasi dengan metodelogi Extreme Programmings. Elex Media Komputindo. 